\title{
Skeletal Hand Charts in Inherited Connective Tissue Disease
}

\author{
J. G. PARISH* \\ From the Departments of Physical Medicine, Dryburn Hospital, Durham, England, \\ and University of Alberta Hospital, Edmonton, Alberta, Canada
}

It is over 60 years since Achard first used radiographs to measure the bones of the hands in a patient who had various skeletal abnormalities and remarkably long fingers. He was interested in finding out why his patient's hands had such a spidery appearance, for which he introduced the term arachnodactyly. He therefore compared measurements of the length of the metacarpals and phalanges obtained from radiographs of his patient's left hand with those of two normal girls of the same age (Achard, 1902). In his patient's hands the metacarpals and proximal phalanges were actually a little shorter than those of a slightly taller normal subject. Only the distal phalanges were slightly longer. $\mathrm{He}$ also measured the width of the proximal and middle phalanges at the centre of the shafts and at the level of the epiphyses at the base of the bones. Differences between the three subjects in width of the base of the bones were negligible, but the phalanges in arachnodactyly were consistently narrower in the middle of the shafts. The significance of Achard's work is that he established that skeletal abnormalities could be caused by alteration of the relation of bone length to width and that the degree of variation from normal could be measured from radiographs of the bones of the hand.

More recently Sinclair has introduced the metacarpal index as a method of distinguishing the hands of patients with arachnodactyly from variations occurring in the hands of normal subjects (Sinclair, Kitchin, and Turner, 1960). By measuring the length of one of the metacarpals or proximal phalanges and dividing this figure by the width of the corresponding shaft, a factor is produced which is relatively constant and independent of bone length. This factor is called the relative slenderness of the bone. The metacarpal index is found by

\footnotetext{
Received April 18, 1967.

Present address: Passmore Edwards Medical Rehabilitation Centre, Clacton-on-Sea, Essex.

averaging the relative slenderness of the $2 \mathrm{nd}, 3 \mathrm{rd}$, 4th, and 5th metacarpals. About this time I noted that the abnormality, which produces the long slender limbs (dolichostenomelia) in Marfan's syndrome, is not always exhibited in the metacarpals. Presumably it can be suppressed by other genetic bone characteristics affecting the metacarpals. I suggested that the proximal phalanges might be more likely to show the Marfan trait and selected the relative slenderness of the 4th proximal phalanx as an index for this abnormality (Parish, 1960). Subsequent work has shown, however, that genetic abnormalities of the skeletal system tend to be expressed very irregularly in the hand. Much more accurate information can be obtained from skeletal hand charts which indicate the deviation from the normal range of the length of the distal phalanges, and of the length, width, and relative slenderness of the metacarpals and proximal phalanges, as well as Sinclair's metacarpal index. This paper will show how the manifestation of three genetically determined bone diseases in the hand can be indicated quantitatively by expressing the abnormal bone measurements in multiples of the standard deviation of those readings from the normal range, and how the results can be plotted in the form of skeletal hand charts.

\section{Method}

Details of the method used to find the exact measurements of the length and width of the metacarpals and phalanges from radiographs of the hands have been given in a previous paper (Parish, 1966). This work included tables giving the mean length and width of the proximal phalanges and metacarpals, length of the distal phalanges and the mean metacarpal indices, with the corresponding standard deviations, in normal male and female right and left hands in subjects between the ages of 21 and 45 years. From these tables the extent of the normal range of bone measurements of the hands has been found by 227 
TABLE I

NORMAL MALE HAND CHART

LIMITS OF TWICE STANDARD DEVIATION FOR ELONGATION AND SLENDERNESS

\begin{tabular}{|c|c|c|c|c|c|c|c|c|c|c|}
\hline \multirow[t]{3}{*}{. } & \multicolumn{10}{|c|}{ Digit } \\
\hline & \multicolumn{5}{|c|}{ Left Hand } & \multicolumn{5}{|c|}{ Right Hand } \\
\hline & 5 & 4 & 3 & 2 & 1 & 1 & 2 & 3 & 4 & 5 \\
\hline $\begin{array}{l}\text { Distal phalanges } \\
\text { Length (mm.) } \\
\text { Proximal phalanges }\end{array}$ & $\uparrow 20.0$ & $23 \cdot 0$ & $21 \cdot 5$ & $20 \cdot 0$ & & & $19 \cdot 5$ & $21 \cdot 0$ & $22 \cdot 0$ & $20 \cdot 0$ \\
\hline $\begin{array}{l}\text { Length (mm.) } \\
\text { Width (mm.) } \\
\text { Relative slenderness index } \\
\text { Metacarpals }\end{array}$ & $\begin{array}{l}\uparrow 37 \\
\downarrow \quad 7 \cdot 5 \\
\uparrow \quad 4 \cdot 4\end{array}$ & $\begin{array}{l}46 \\
9 \cdot 0 \\
4 \cdot 7\end{array}$ & $\begin{array}{l}50 \\
10 \cdot 0 \\
4 \cdot 6\end{array}$ & $\begin{array}{l}45 \\
9 \cdot 5 \\
4 \cdot 2\end{array}$ & $\begin{array}{l}34 \\
8 \cdot 0 \\
4 \cdot 0\end{array}$ & $\begin{array}{r}34 \\
7 \cdot 5 \\
4 \cdot 1\end{array}$ & $\begin{array}{r}45 \\
10 \cdot 0 \\
4 \cdot 2\end{array}$ & $\begin{array}{l}50 \\
10 \cdot 0 \\
4 \cdot 6\end{array}$ & $\begin{array}{r}47 \\
9 \cdot 5 \\
4 \cdot 6\end{array}$ & $\begin{array}{r}37 \\
7 \cdot 5 \\
4 \cdot 4\end{array}$ \\
\hline $\begin{array}{l}\text { Length } \\
\text { Width } \\
\text { Relative slenderness index } \\
\text { Metacarpal index }\end{array}$ & $\begin{array}{ll}\uparrow & 60 \\
\downarrow & 7 \cdot 5 \\
\uparrow & 7 \cdot 6 \\
\uparrow & \end{array}$ & $\begin{array}{r}65 \\
6 \cdot 5 \\
9 \cdot 2\end{array}$ & $\begin{array}{l}73 \\
8 \cdot 0 \\
8 \cdot 3\end{array}$ & $\begin{array}{l}75 \\
8 \cdot 0 \\
8 \cdot 5 \\
8 \cdot 0\end{array}$ & $\begin{array}{r}52 \\
9 \cdot 5 \\
4 \cdot 9\end{array}$ & $\begin{array}{l}52 \\
9 \cdot 0 \\
5 \cdot 0\end{array}$ & $\begin{array}{l}76 \\
8 \cdot 0 \\
8 \cdot 5 \\
7 \cdot 7\end{array}$ & $\begin{array}{l}72 \\
8 \cdot 0 \\
8 \cdot 1\end{array}$ & $\begin{array}{l}65 \\
6 \cdot 5 \\
9 \cdot 1\end{array}$ & $\begin{array}{l}60 \\
7 \cdot 5 \\
7 \cdot 3\end{array}$ \\
\hline
\end{tabular}

TABLE II NORMAL MALE HAND CHART:
LIMITS OF THREE TIMES STANDARD DEVIATION FOR ELONGATION AND SLENDERNESS

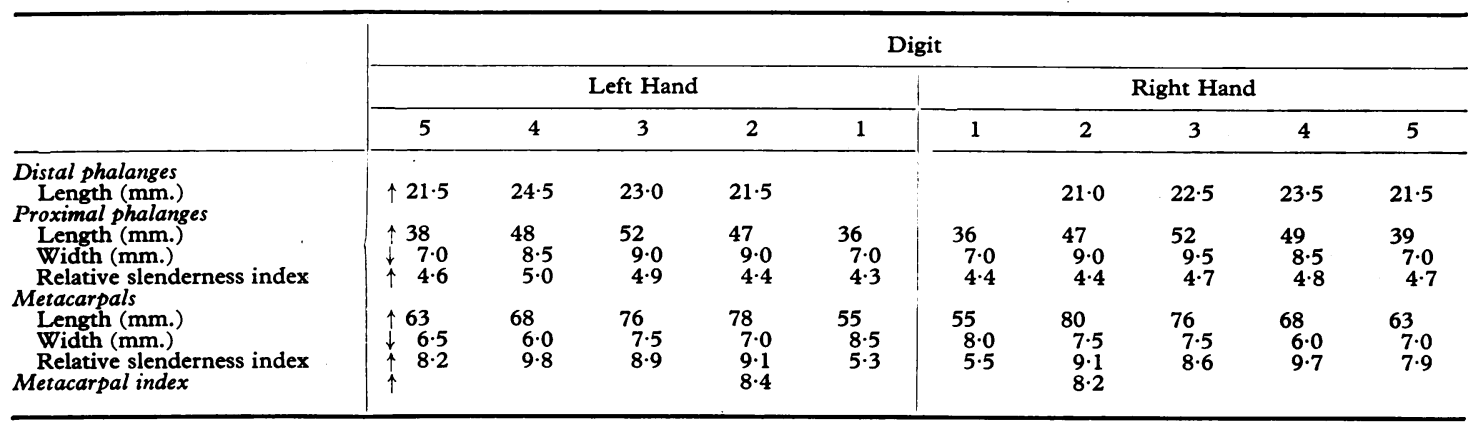

TABLE III

NORMAL MALE HAND CHART: LIMITS OF TWICE STANDARD DEVIATION FOR SHORTNESS AND BREADTH

\begin{tabular}{|c|c|c|c|c|c|c|c|c|c|c|}
\hline & \multicolumn{10}{|c|}{ Digit } \\
\hline & \multicolumn{5}{|c|}{ Left Hand } & \multicolumn{5}{|c|}{ Right Hand } \\
\hline & 5 & 4 & 3 & 2 & 1 & 1 & 2 & 3 & 4 & 5 \\
\hline $\begin{array}{l}\text { Distal phalanges } \\
\text { Length (mm.) } \\
\text { Proximal phalanges }\end{array}$ & 14.5 & $16 \cdot 0$ & $16 \cdot 0$ & $14 \cdot 5$ & & & $15 \cdot 0$ & $16 \cdot 0$ & $16 \cdot 5$ & $14 \cdot 0$ \\
\hline $\begin{array}{l}\text { Length (mm.) } \\
\text { Width (mm.) } \\
\text { Relative slenderness index } \\
\text { Metacarpals }\end{array}$ & $\begin{array}{l}\downarrow 31 \\
\uparrow 9.5 \\
\downarrow 3.5\end{array}$ & $\begin{array}{l}40 \\
11 \cdot 5 \\
3 \cdot 7\end{array}$ & $\begin{array}{l}42 \\
12.5 \\
3.6\end{array}$ & $\begin{array}{l}37 \\
12 \cdot 0 \\
3 \cdot 4\end{array}$ & $\begin{array}{l}28 \\
10 \cdot 5 \\
2 \cdot 8\end{array}$ & $\begin{array}{l}28 \\
10 \cdot 5 \\
2 \cdot 8\end{array}$ & $\begin{array}{l}37 \\
12 \cdot 0 \\
3 \cdot 3\end{array}$ & $\begin{array}{r}41 \\
12.5 \\
3.6\end{array}$ & $\begin{array}{l}39 \\
11.5 \\
3.6\end{array}$ & $\begin{array}{r}31 \\
9.5 \\
3.5\end{array}$ \\
\hline $\begin{array}{l}\text { Length (mm.) } \\
\text { Width (mm.) } \\
\text { Relative slenderness index } \\
\text { Metacarpal index }\end{array}$ & $\begin{array}{l}\downarrow 50 \\
\uparrow 10 \cdot 0 \\
\downarrow \\
\downarrow\end{array}$ & $\begin{array}{l}54 \\
8 \cdot 5 \\
6 \cdot 8\end{array}$ & $\begin{array}{l}60 \\
10 \cdot 5 \\
6 \cdot 2\end{array}$ & $\begin{array}{r}62 \\
10 \cdot 5 \\
6 \cdot 3 \\
6 \cdot 1\end{array}$ & $\begin{array}{l}40 \\
12 \cdot 5 \\
3 \cdot 6\end{array}$ & $\begin{array}{r}41 \\
13 \cdot 0 \\
3 \cdot 5\end{array}$ & $\begin{array}{r}61 \\
11 \cdot 0 \\
6 \cdot 1 \\
6 \cdot 0\end{array}$ & $\begin{array}{l}60 \\
10 \cdot 5 \\
6 \cdot 2\end{array}$ & $\begin{array}{r}54 \\
8 \cdot 5 \\
6 \cdot 6\end{array}$ & $\begin{array}{l}50 \\
10 \cdot 5 \\
5 \cdot 1\end{array}$ \\
\hline
\end{tabular}

deviation ( 2 SD) and $3 \times$ standard deviation ( 3 SD) for the following:

(a) Elongation and slenderness in the normal male hand (Tables I and II).

(b) Shortness and breadth in the normal male hand (Tables III and IV).

(c) Elongation and slenderness in the normal female hand (Tables V and VI). (d) Shortness and breadth of the bones in the normal female hand (Tables VII and VIII).

The arrows on these charts indicate whether a reading should be greater or less than those recorded to be outside the corresponding standard deviation. In the abnormal skeletal hand chart, readings outside 2 or 3 SD for elongation or slenderness are underlined by continuous lines twice or three times, respectively. Similarly, 
TABLE IV

NORMAL MALE HAND CHART:

LIMITS OF THREE TIMES STANDARD DEVIATION FOR SHORTNESS AND BREADTH

\begin{tabular}{|c|c|c|c|c|c|c|c|c|c|c|}
\hline & \multicolumn{10}{|c|}{ Digit } \\
\hline & \multicolumn{5}{|c|}{ Left Hand } & \multicolumn{5}{|c|}{ Right Hand } \\
\hline & 5 & 4 & 3 & 2 & 1 & 1 & 2 & 3 & 4 & 5 \\
\hline $\begin{array}{l}\text { Distal phalanges } \\
\text { Length (mm.) } \\
\text { Proximal phalanges }\end{array}$ & $\downarrow 13 \cdot 0$ & $14 \cdot 0$ & $14 \cdot 5$ & $13 \cdot 0$ & & & $14 \cdot 0$ & 14.5 & $15 \cdot 0$ & $12 \cdot 5$ \\
\hline $\begin{array}{l}\text { Length (mm.) } \\
\text { Width (mm.) } \\
\text { Relative slenderness index } \\
\text { Metacarpals }\end{array}$ & $\begin{array}{l}\downarrow 29 \\
\uparrow 10 \cdot 0 \\
\downarrow 3.3\end{array}$ & $\begin{array}{l}38 \\
12 \cdot 0 \\
3 \cdot 4\end{array}$ & $\begin{array}{l}39 \\
13 \cdot 5 \\
3 \cdot 3\end{array}$ & $\begin{array}{l}35 \\
12 \cdot 5 \\
3 \cdot 2\end{array}$ & $\begin{array}{l}26 \\
11 \cdot 0 \\
2 \cdot 5\end{array}$ & $\begin{aligned} 26 \\
11 \cdot 5 \\
2 \cdot 5\end{aligned}$ & $\begin{array}{l}35 \\
13 \cdot 0 \\
3 \cdot 1\end{array}$ & $\begin{array}{l}39 \\
13 \cdot 5 \\
3 \cdot 3\end{array}$ & $\begin{array}{l}37 \\
12 \cdot 5 \\
3 \cdot 4\end{array}$ & $\begin{array}{r}29 \\
10 \cdot 5 \\
3 \cdot 2\end{array}$ \\
\hline $\begin{array}{l}\text { Length (mm.) } \\
\text { Width (mm.) } \\
\text { Relative slenderness index } \\
\text { Metacarpal index }\end{array}$ & $\begin{array}{l}\downarrow 48 \\
\uparrow 10.5 \\
\downarrow 4.7 \\
\downarrow\end{array}$ & $\begin{array}{l}50 \\
9 \cdot 0 \\
6 \cdot 1\end{array}$ & $\begin{array}{l}57 \\
11 \cdot 0 \\
5 \cdot 6\end{array}$ & $\begin{array}{l}59 \\
11 \cdot 5 \\
5 \cdot 7 \\
5 \cdot 6\end{array}$ & $\begin{array}{r}37 \\
13 \cdot 5 \\
3 \cdot 2\end{array}$ & $\begin{array}{r}38 \\
14 \cdot 0 \\
3 \cdot 0\end{array}$ & $\begin{array}{r}58 \\
11 \cdot 5 \\
5 \cdot 5 \\
5 \cdot 5\end{array}$ & $\begin{array}{r}57 \\
11 \cdot 0 \\
5 \cdot 7\end{array}$ & $\begin{array}{l}51 \\
9 \cdot 0 \\
6 \cdot 0\end{array}$ & $\begin{array}{r}48 \\
11 \cdot 0 \\
4 \cdot 5\end{array}$ \\
\hline
\end{tabular}

TABLE V

NORMAL FEMALE HAND CHART LIMITS OF TWICE STANDARD DEVIATION FOR ELONGATION AND SLENDERNESS

\begin{tabular}{|c|c|c|c|c|c|c|c|c|c|c|}
\hline & \multicolumn{10}{|c|}{ Digit } \\
\hline & \multicolumn{5}{|c|}{ Left Hand } & \multicolumn{5}{|c|}{ Right Hand } \\
\hline & 5 & 4 & 3 & 2 & 1 & 1 & 2 & 3 & 4 & 5 \\
\hline $\begin{array}{l}\text { Distal phalanges } \\
\text { Length (mm.) } \\
\text { Proximal phalanges }\end{array}$ & $\uparrow 17.5$ & $20 \cdot 0$ & 19.5 & $18 \cdot 0$ & & & $18 \cdot 5$ & $19 \cdot 0$ & $20 \cdot 0$ & $17 \cdot 5$ \\
\hline $\begin{array}{l}\text { Length (mm.) } \\
\text { Width (mm.) } \\
\text { Relative slenderness index } \\
\text { Metacarpals }\end{array}$ & $\begin{array}{ll}\uparrow 34 \\
\downarrow & 6 \cdot 0 \\
\uparrow & 5 \cdot 1\end{array}$ & $\begin{array}{r}43 \\
7 \cdot 5 \\
5 \cdot 4\end{array}$ & $\begin{array}{r}46 \\
8 \cdot 0 \\
5 \cdot 2\end{array}$ & $\begin{array}{r}41 \\
8 \cdot 5 \\
4 \cdot 7\end{array}$ & $\begin{array}{r}31 \\
6 \cdot 5 \\
4 \cdot 4\end{array}$ & $\begin{array}{l}31 \\
7 \cdot 0 \\
4 \cdot 3\end{array}$ & $\begin{array}{r}41 \\
8 \cdot 5 \\
4 \cdot 6\end{array}$ & $\begin{array}{r}46 \\
8 \cdot 5 \\
5 \cdot 1\end{array}$ & $\begin{array}{r}43 \\
7 \cdot 5 \\
5 \cdot 3\end{array}$ & $\begin{array}{c}34 \\
6 \cdot 0 \\
5 \cdot 1\end{array}$ \\
\hline $\begin{array}{l}\text { Length (mm.) } \\
\text { Width (mm.) } \\
\text { Relative slenderness index } \\
\text { Metacarpal index }\end{array}$ & $\begin{array}{ll}\uparrow & 56 \\
\downarrow & 6 \cdot 0 \\
\uparrow & 8.6 \\
\uparrow & \end{array}$ & $\begin{array}{r}60 \\
5 \cdot 5 \\
10 \cdot 6\end{array}$ & $\begin{array}{r}68 \\
7 \cdot 0 \\
8 \cdot 9\end{array}$ & $\begin{array}{l}70 \\
7 \cdot 0 \\
9 \cdot 3 \\
8 \cdot 7\end{array}$ & $\begin{array}{r}47 \\
8 \cdot 0 \\
5 \cdot 5\end{array}$ & $\begin{array}{r}47 \\
8 \cdot 0 \\
5 \cdot 5\end{array}$ & $\begin{array}{c}70 \\
7.0 \\
9.3 \\
8.6\end{array}$ & $\begin{array}{c}68 \\
7 \cdot 0 \\
9 \cdot 0\end{array}$ & $\begin{array}{r}61 \\
5.5 \\
10.4\end{array}$ & $\begin{array}{l}56 \\
6.5 \\
8.3\end{array}$ \\
\hline
\end{tabular}

TABLE VI

NORMAL FEMALE HAND CHART LIMITS OF THREE TIMES STANDARD DEVIATION FOR ELONGATION AND SLENDERNESS

\begin{tabular}{|c|c|c|c|c|c|c|c|c|c|c|}
\hline & \multicolumn{10}{|c|}{ Digit } \\
\hline & \multicolumn{5}{|c|}{ Left Hand } & \multicolumn{5}{|c|}{ Right Hand } \\
\hline & 5 & 4 & 3 & 2 & 1 & 1 & 2 & 3 & 4 & 5 \\
\hline $\begin{array}{l}\text { Distal phalanges } \\
\text { Length (mm.) } \\
\text { Proximal phalanges }\end{array}$ & $\uparrow 19 \cdot 0$ & 21.5 & $20 \cdot 5$ & $19 \cdot 5$ & & & $19 \cdot 5$ & $20 \cdot 5$ & $21 \cdot 0$ & $19 \cdot 0$ \\
\hline $\begin{array}{l}\text { Length (mm.) } \\
\text { Width (mm.) } \\
\text { Relative slenderness index } \\
\text { Metacarpals }\end{array}$ & $\begin{array}{l}\uparrow 35 \\
\downarrow \quad 5.5 \\
\uparrow \quad 5.5\end{array}$ & $\begin{array}{l}45 \\
6 \cdot 5 \\
5 \cdot 7\end{array}$ & $\begin{array}{c}48 \\
7 \cdot 5 \\
5 \cdot 5\end{array}$ & $\begin{array}{r}43 \\
7 \cdot 5 \\
4 \cdot 9\end{array}$ & $\begin{array}{l}33 \\
6 \cdot 0 \\
4 \cdot 7\end{array}$ & $\begin{array}{l}33 \\
6.0 \\
4.6\end{array}$ & $\begin{array}{l}43 \\
8 \cdot 0 \\
4 \cdot 9\end{array}$ & $\begin{array}{l}48 \\
8 \cdot 0 \\
5 \cdot 4\end{array}$ & $\begin{array}{r}45 \\
7 \cdot 0 \\
5 \cdot 6\end{array}$ & $\begin{array}{l}36 \\
5 \cdot 5 \\
5 \cdot 5\end{array}$ \\
\hline $\begin{array}{l}\text { Length (mm.) } \\
\text { Width (mm.) } \\
\text { Relative slenderness index } \\
\text { Metacarpal index }\end{array}$ & $\begin{array}{ll}\uparrow & 58 \\
\downarrow & 5 \cdot 5 \\
\uparrow & 9 \cdot 2 \\
\uparrow & \end{array}$ & $\begin{array}{r}63 \\
5.0 \\
11 \cdot 4\end{array}$ & $\begin{array}{c}71 \\
6 \cdot 5 \\
9 \cdot 4\end{array}$ & $\begin{array}{l}73 \\
6 \cdot 5 \\
9 \cdot 9 \\
9 \cdot 2\end{array}$ & $\begin{array}{r}49 \\
7 \cdot 0 \\
5 \cdot 9\end{array}$ & $\begin{array}{l}49 \\
7 \cdot 0 \\
6 \cdot 0\end{array}$ & $\begin{array}{l}74 \\
6 \cdot 5 \\
9 \cdot 9 \\
9 \cdot 1\end{array}$ & $\begin{array}{r}71 \\
6 \cdot 5 \\
9 \cdot 6\end{array}$ & $\begin{array}{r}64 \\
5 \cdot 0 \\
11 \cdot 2\end{array}$ & $\begin{array}{r}59 \\
5 \cdot 5 \\
8 \cdot 9\end{array}$ \\
\hline
\end{tabular}

measurements outside 2 or 3 SD for shortness or breadth are underlined by broken lines.

Example 1: a 5 th proximal phalanx in a male left hand measured $33 \mathrm{~mm}$. in length and $7.0 \mathrm{~mm}$. in width; the relative slenderness would be $4 \cdot 7$. Reference to Table I indicates that the length was well within the normal range, the upper limit of 2 SD for elongation being 37 $\mathrm{mm}$. and for shortness being $31 \mathrm{~mm}$. (Table III). The width, however, is below the $2 \mathrm{SD}$ for slenderness of $7.5 \mathrm{~mm}$. (Table I) but within the $3 \mathrm{SD}$ limit of $7.0 \mathrm{~mm}$. (Table II) and would be recorded 7.0. The relative slenderness is greater than the $3 \mathrm{SD} \overline{\overline{\text { for }}}$ this bone $(4 \cdot 6$, Table II) and would be recorded $4 \cdot 7$.

This bone was significantly slender for its length and could be expected to occcur no more frequently than approximately once in 750 hands. 
TABLE VII

NORMAL FEMALE HAND CHART:

LIMITS OF TWICE STANDARD DEVIATION FOR SHORTNESS AND BREADTH

\begin{tabular}{|c|c|c|c|c|c|c|c|c|c|c|}
\hline & \multicolumn{10}{|c|}{ Digit } \\
\hline & \multicolumn{5}{|c|}{ Left Hand } & \multicolumn{5}{|c|}{ Right Hand } \\
\hline & 5 & 4 & 3 & 2 & 1 & 1 & 2 & 3 & 4 & 5 \\
\hline $\begin{array}{l}\text { Distal phalanges } \\
\text { Length (mm.) } \\
\text { Proximal phalanges }\end{array}$ & $\downarrow 13.0$ & $15 \cdot 0$ & $15 \cdot 0$ & $13 \cdot 5$ & & & 13.5 & $14 \cdot 5$ & $15 \cdot 0$ & $13 \cdot 0$ \\
\hline $\begin{array}{l}\text { Length (mm.) } \\
\text { Width (mm.) } \\
\text { Relative slenderness index } \\
\text { Metacarpals }\end{array}$ & $\begin{array}{l}\downarrow 28 \\
\uparrow 8.0 \\
\downarrow 3 \cdot 7\end{array}$ & $\begin{array}{l}36 \\
9 \cdot 5 \\
4 \cdot 0\end{array}$ & $\begin{array}{l}38 \\
10 \cdot 0 \\
4 \cdot 0\end{array}$ & $\begin{array}{l}35 \\
10 \cdot 0 \\
3 \cdot 7\end{array}$ & $\begin{array}{l}26 \\
8 \cdot 5 \\
3 \cdot 1\end{array}$ & $\begin{array}{l}26 \\
8 \cdot 5 \\
3 \cdot 1\end{array}$ & $\begin{array}{r}35 \\
10.5 \\
3.6\end{array}$ & $\begin{array}{r}39 \\
10 \cdot 5 \\
3 \cdot 9\end{array}$ & $\begin{array}{l}36 \\
9 \cdot 5 \\
4 \cdot 0\end{array}$ & $\begin{array}{r}28 \\
8 \cdot 0 \\
3 \cdot 7\end{array}$ \\
\hline $\begin{array}{l}\text { Length (mm.) } \\
\text { Width (mm.) } \\
\text { Relative slenderness index } \\
\text { Metacarpal index }\end{array}$ & $\begin{array}{ll}\downarrow & 47 \\
\uparrow & 8 \cdot 0 \\
\downarrow & 5.9 \\
\downarrow & \end{array}$ & $\begin{array}{l}50 \\
7 \cdot 0 \\
7 \cdot 5\end{array}$ & $\begin{array}{l}56 \\
8 \cdot 5 \\
6 \cdot 8\end{array}$ & $\begin{array}{l}58 \\
9 \cdot 0 \\
7 \cdot 0 \\
6 \cdot 8\end{array}$ & $\begin{array}{l}38 \\
10 \cdot 0 \\
3.9\end{array}$ & $\begin{array}{r}39 \\
10 \cdot 5 \\
3 \cdot 9\end{array}$ & $\begin{array}{l}58 \\
9 \cdot 0 \\
6 \cdot 8 \\
6 \cdot 6\end{array}$ & $\begin{array}{l}56 \\
9 \cdot 0 \\
6 \cdot 6\end{array}$ & $\begin{array}{l}50 \\
7 \cdot 5 \\
7 \cdot 2\end{array}$ & $\begin{array}{r}47 \\
8 \cdot 5 \\
5 \cdot 8\end{array}$ \\
\hline
\end{tabular}

TABLE VIII

NORMAL FEMALE HAND CHART:

LIMITS OF THREE TIMES STANDARD DEVIATION FOR SHORTNESS AND BREADTH

\begin{tabular}{|c|c|c|c|c|c|c|c|c|c|c|}
\hline & \multicolumn{10}{|c|}{ Digit } \\
\hline & \multicolumn{5}{|c|}{ Left Hand } & \multicolumn{5}{|c|}{ Right Hand } \\
\hline & 5 & 4 & 3 & 2 & 1 & 1 & 2 & 3 & 4 & 5 \\
\hline $\begin{array}{l}\text { Distal phalanges } \\
\text { Length (mm.) } \\
\text { Proximal phalanges }\end{array}$ & $\downarrow 12 \cdot 0$ & 13.5 & $13 \cdot 5$ & $12 \cdot 5$ & & & $12 \cdot 0$ & 13.5 & 13.5 & 11.5 \\
\hline $\begin{array}{l}\text { Length (mm.) } \\
\text { Width (mm.) } \\
\text { Relative slenderness index } \\
\text { Metacarpals }\end{array}$ & $\begin{array}{l}\downarrow 27 \\
\uparrow 8.5 \\
\downarrow 3 \cdot 3\end{array}$ & $\begin{array}{l}34 \\
10 \cdot 0 \\
3.7\end{array}$ & $\begin{array}{l}36 \\
11 \cdot 0 \\
3.7\end{array}$ & $\begin{array}{l}33 \\
10.5 \\
3.5\end{array}$ & $\begin{array}{c}24 \\
9.5 \\
2.7\end{array}$ & $\begin{array}{c}24 \\
9 \cdot 5 \\
2 \cdot 8\end{array}$ & $\begin{array}{r}33 \\
11 \cdot 0 \\
3 \cdot 3\end{array}$ & $\begin{array}{l}36 \\
11.0 \\
3.6\end{array}$ & $\begin{array}{r}34 \\
10 \cdot 0 \\
3 \cdot 7\end{array}$ & $\begin{array}{r}27 \\
8 \cdot 5 \\
3 \cdot 3\end{array}$ \\
\hline $\begin{array}{l}\text { Length (mm.) } \\
\text { Width (mm.) } \\
\text { Relative slenderness index } \\
\text { Metacarpal index }\end{array}$ & $\begin{array}{l}\downarrow 44 \\
\uparrow 9 \cdot 0 \\
\downarrow 5 \cdot 3 \\
\downarrow\end{array}$ & $\begin{array}{c}47 \\
7 \cdot 5 \\
6 \cdot 7\end{array}$ & $\begin{array}{l}53 \\
9 \cdot 5 \\
6 \cdot 3\end{array}$ & $\begin{array}{l}55 \\
9 \cdot 5 \\
6 \cdot 4 \\
6 \cdot 4\end{array}$ & $\begin{array}{l}36 \\
11 \cdot 0 \\
3.5\end{array}$ & $\begin{array}{l}36 \\
11 \cdot 0 \\
3 \cdot 5\end{array}$ & $\begin{array}{l}55 \\
9 \cdot 5 \\
6 \cdot 2 \\
6 \cdot 1\end{array}$ & $\begin{array}{l}53 \\
9 \cdot 5 \\
5 \cdot 9\end{array}$ & $\begin{array}{l}48 \\
8 \cdot 0 \\
6 \cdot 3\end{array}$ & $\begin{array}{r}44 \\
9 \cdot 0 \\
5 \cdot 2\end{array}$ \\
\hline
\end{tabular}

Example 2: the second metacarpal in a female right hand measured $64 \mathrm{~mm}$. in length and $10.5 \mathrm{~mm}$. in width; the relative slenderness would be $6 \cdot 1$. Reference to Table $\mathrm{V}$ indicates that the length was well within the limit for the 2 SD for elongation of $70 \mathrm{~mm}$. and for shortness of $58 \mathrm{~mm}$. (Table VII). The width is outside the $2 \mathrm{SD}$ for breadth of $9.0 \mathrm{~mm}$. (Table VII), the $3 \mathrm{SD}$ of $9.5 \mathrm{~mm}$. (Table VIII) and is probably outside the limit of $4 \mathrm{SD}$ for breadth; reference to Table VIII of the previous paper (Parish, 1966) reveals that the 4 SD for breadth of this bone is exactly $10 \cdot 50$, so that it would be recorded 10.5. The relative slenderness is less than

the 3 SD for the breadth of this bone of $6 \cdot 2$ (Table VIII) and would be recorded $6 \cdot 1$. This bone was extremely

broad for its length, the differences being significantly abnormal.

It should be noted that in metacarpal index measurements the width of the metacarpal is estimated at the exact midpoint of the shaft. In all other measurements of the relative slenderness of either proximal phalanges or the metacarpals the width is estimated at the narrowest point of the shaft.

Since standard deviation readings relate to the complete range of the normal hand measurements, a reading outside 2 SD towards either elongation or shortness will occur no more frequently than once in 40 hands in each direction; readings outside 2 SD for either slenderness or breadth occur with similar frequency.

\section{Results}

The Original Case of Arachnodactyly. The skeletal hand chart of Achard's 18-year-old patient has been reconstructed from the bone measurements which he published in 1902 (Table IX). Points to be noted are: (1) the normal length of the metacarpals and phalanges; (2) only the width of the 2nd and 4th proximal phalanges is somewhat below normal (outside 2 SD for slenderness); (3) the significantly high indices of relative slenderness for three of the phalanges (outside 3 SD for slenderness).

Thus, the importance of the relative slenderness index as an indicator of abnormality is at once apparent. Unfortunately, Achard did not record the widths of the metacarpals, so that the hand chart cannot be completed.

Marfan's Syndrome. In 1896 Antoine Marfan described a skeletal disorder in a 5-year-old girl 
TABLE IX

ARACHNODACTYLY:

FEMALE LEFT HAND CHART OF ACHARD'S ORIGINAL PATIENT

\begin{tabular}{|c|c|c|c|c|c|}
\hline & \multicolumn{5}{|c|}{ Digit } \\
\hline & 5 & 4 & 3 & 2 & 1 \\
\hline Distal phalanges & 17 & 19 & 19 & 18 & \\
\hline $\begin{array}{l}\text { Proxtmal phalanges } \\
\text { Length (mm.) } \\
\text { Width (mm.) }\end{array}$ & 33 & $\begin{array}{c}42 \\
7.0 \\
\end{array}$ & $\stackrel{45}{8 \cdot 0}$ & $\stackrel{40}{8 \cdot 0}$ & 30 \\
\hline Relative slenderness index & $5 \cdot 5$ & $6 \cdot 0$ & $5 \cdot 6$ & $5 \cdot 0$ & 一 \\
\hline $\begin{array}{l}\text { Metacarpals } \\
\text { Length (mm.) }\end{array}$ & 57 & 63 & 70 & 72 & 45 \\
\hline
\end{tabular}

$=$ Outside $2 \times$ SD for slenderness or high index of relative slenderness.

$\equiv$ Outside $3 \times \mathrm{SD}$ for high indices of relative slenderness.

TABLE $\mathrm{X}$

ARACHNODACTYLY:

HAND CHART OF FEMALE PATIENT WITH AORTIC AND OCULAR CHANGES OF MARFAN'S SYNDROME

\begin{tabular}{|c|c|c|c|c|c|c|c|c|c|c|}
\hline & \multicolumn{10}{|c|}{ Digit } \\
\hline & \multicolumn{5}{|c|}{ Left Hand } & \multicolumn{5}{|c|}{ Right Hand } \\
\hline & 5 & 4 & 3 & 2 & 1 & 1 & 2 & 3 & 4 & 5 \\
\hline $\begin{array}{l}\text { Distal phalanges } \\
\text { Length (mm.) } \\
\text { Proximal phalanges }\end{array}$ & $16 \cdot 5$ & $18 \cdot 0$ & $18 \cdot 0$ & $17 \cdot 0$ & & & 16.5 & $17 \cdot 5$ & $18 \cdot 0$ & $16 \cdot 0$ \\
\hline Length (mm.) & 33 & 41 & 43 & 41 & 32 & 32 & 41 & 44 & 41 & 33 \\
\hline Width (mm.) & $6 \cdot 0$ & 7.5 & $8 \cdot 0$ & 7.5 & $7 \cdot 0$ & 6.5 & 7.5 & $8 \cdot 0$ & $7 \cdot 5$ & $5 \cdot 5$ \\
\hline Relative slenderness index & $5 \cdot 5$ & $5 \cdot 4$ & $\underline{5 \cdot 4}$ & $\overline{\overline{5.4}}$ & $4 \cdot 6$ & $\overline{\overline{4.9}}$ & 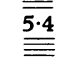 & $\overline{5.5}$ & $\underline{5.4}$ & $\overline{6.0}$ \\
\hline $\begin{array}{l}\text { Metacarpals } \\
\text { Length (mm.) } \\
\text { Width (mm.) }\end{array}$ & $\begin{aligned} 51 \\
6.5\end{aligned}$ & $\begin{array}{l}57 \\
5.5\end{array}$ & $\underset{7.0}{65}$ & $\stackrel{66}{7 \cdot 0}$ & $\begin{array}{l}43 \\
8.5\end{array}$ & $\begin{array}{l}44 \\
8 \cdot 5\end{array}$ & $\begin{array}{l}68 \\
7.5\end{array}$ & $\begin{array}{l}67 \\
7.5\end{array}$ & $\stackrel{59}{6 \cdot 0}$ & $\begin{array}{r}52 \\
6.0 \\
\end{array}$ \\
\hline Relative slenderness index & $7 \cdot 8$ & $10 \cdot 2$ & $9 \cdot 3$ & $9 \cdot 4$ & $5 \cdot 1$ & $5 \cdot 2$ & $9 \cdot 1$ & $8 \cdot 8$ & $9 \cdot 8$ & 8.7 \\
\hline Metacarpal index & & & & 8.5 & & & $8 \cdot 8$ & & & \\
\hline
\end{tabular}

= Outside 2 SD for elongation, slenderness, or high indices of relative slenderness.

Outside 3 SD for slenderness or high indices of relative slenderness.

Outside 4 SD for high indices of relative slenderness.

producing excessive lengthening and slenderness of the arms and the legs, especially in the hands and feet. The lack of subcutaneous fat and poor muscular development accentuated the effect of the long slender bones. He called the condition 'dolichosténomélie' (long narrow limbs). The patient did not show any eye defects and her heart was normal, but her sister had been operated on for a strabismus, and her brother had a congenital cataract, which indicates an unusual prevalence of congenital eye defects in the family. Although the modern concept of Marfan's syndrome relates congenital eye and cardiac abnormalities to the skeletal changes, the cardiac defects were not described until 1912 by Salle and the eye changes (dislocation of the lens and myopia in particular) by Boerger in 1914.

Table $\mathrm{X}$ is the skeletal hand chart of a 40 -year-old woman with the characteristic long slender limbs (dolichostenomelia) described by Marfan. The radiograph of the hands is shown in Fig. 1. She had dilatation of the ascending aorta and a divergent strabismus of her right eye with a progressive myopia of this eye. She had considerable ligament laxity, more pronounced on the right side of the body, resulting in recurrent dislocation of the patellae and of the peroneal tendons, and metatarsus quintus valgus deformity in her right foot, which has been illustrated previously (Parish, 1960). Her skeletal hand chart shows: (1) normal bone lengths except for slight elongation of the first proximal phalanges; (2) the metacarpals, virtually normal, with only the width of the 5th right metacarpal and two of the relative slenderness indices much outside the 2 SD of the normal distribution; (3) the proximal phalanges, 


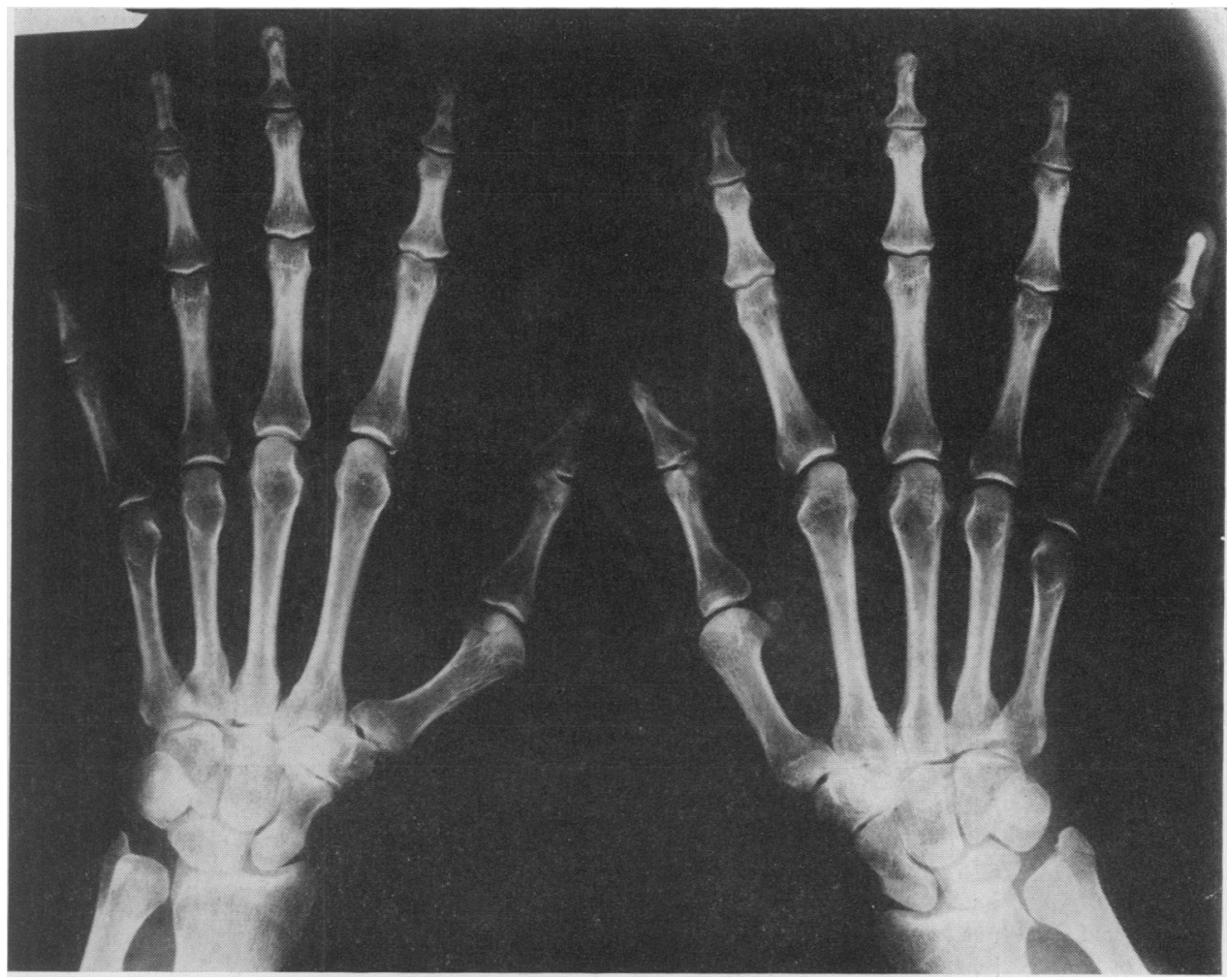

Fig. 1. Radiograph of hands of patient with the Marfan syndrome.

severely affected, with some of the relative slenderness indices reaching beyond the 3 and 4 SD levels of the normal range; (4) the expression of the arachnodactyly defect is very irregular, being more pronounced in the right hand, and not expressed at all in the left ring finger, which shows normal bone measurements.

Achard's Syndrome. The skeletal abnormalities described by Achard in his patient in 1902 were very different from Marfan's syndrome. The bone changes were entirely confined to the hands and the feet; there was no dolichostenomelia. The muscles were well developed and subcutaneous fat abundant. The broad brachycephalic skull with a small mandible presented a completely different appearance from the narrow dolichocephalic skull with prognathism frequently found in Marfan's syndrome. Table XI is the skeletal hand chart measured from the radiograph (Fig. 2) of a 38-yearold woman with Achard's syndrome described previously (Parish, 1960). Her skeletal hand chart shows: (1) normal bone lengths except for slight elongation of the proximal phalanx of the left thumb; (2) both the metacarpals and proximal phalanges are severely affected with relative slenderness indices reaching beyond the $6 \mathrm{SD}$ level of the normal range in the 4th proximal phalanx and 3rd metacarpal of the right hand. The arachnodactyly defect is thus much greater than in the previous case of Marfan's syndrome, though there were no ocular or cardiac abnormalities; (3) the arachnodactyly trait is expressed very irregularly; in fact, the 3rd proximal phalanx of the left hand was completely normal.

Tall Normal Subjects. The hand chart of a normal female subject, $176 \mathrm{~cm}$. (5 ft. $10 \frac{1}{2} \mathrm{in}$.) in height, is presented in Table XII. All the distal phalanges and several proximal phalanges and metacarpals are outside 2 SD for length, but the width and relative slenderness indices remain within the 2 SD limit. In taller subjects the hand charts have shown fewer bones outside the 2 SD level, while an occasional bone has measured outside $2 \mathrm{SD}$ for breadth, but in all cases the relative slenderness index has remained within the 2 SD limits. 


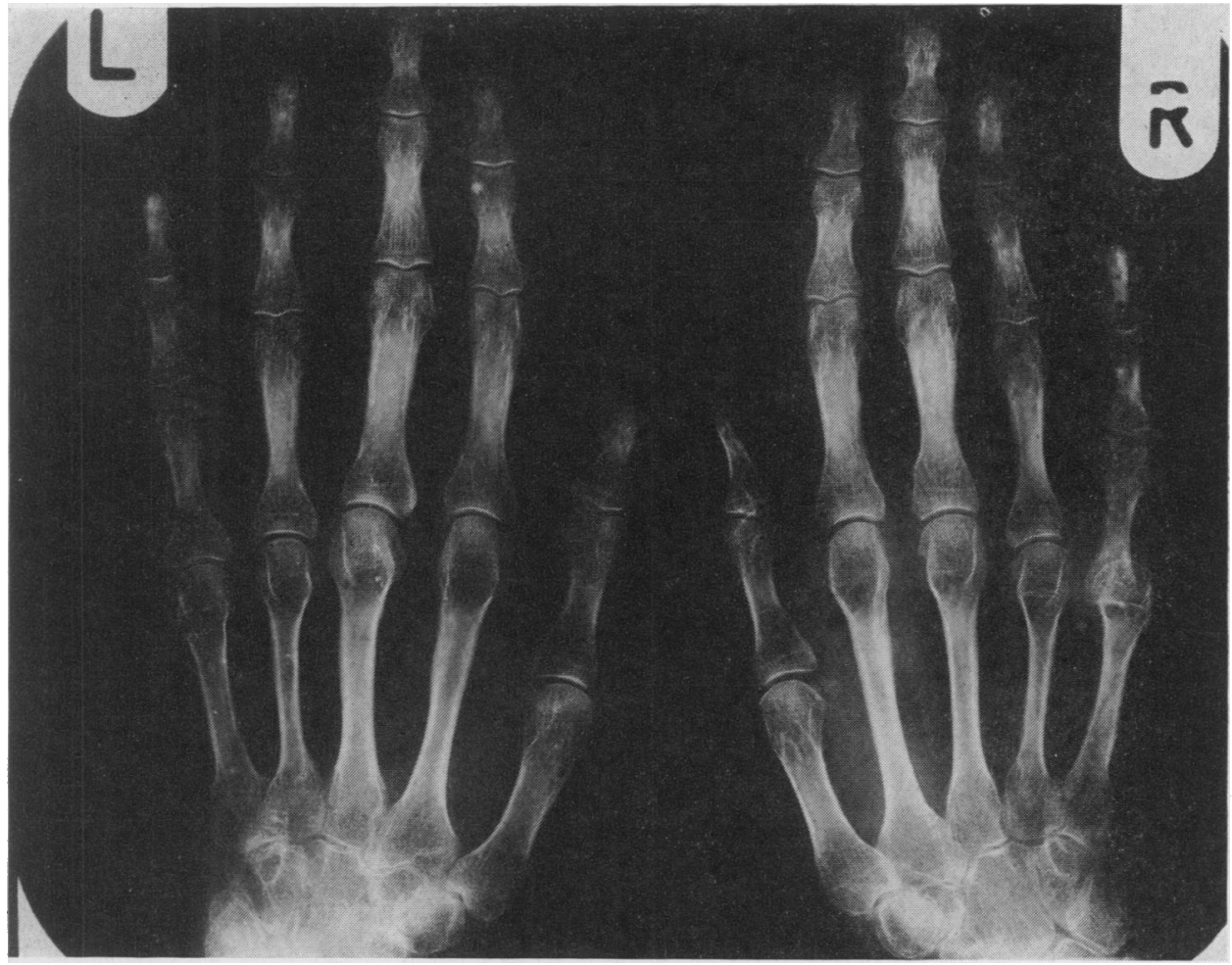

Fig. 2. Achard's syndrome. There is dislocation of the 5th right metacarpal-phalangeal joint.

TABLE XI

ARACHNODACTYLY:

HAND CHART OF FEMALE PATIENT WITH SKELETAL CHANGES OF ACHARD'S SYNDROME

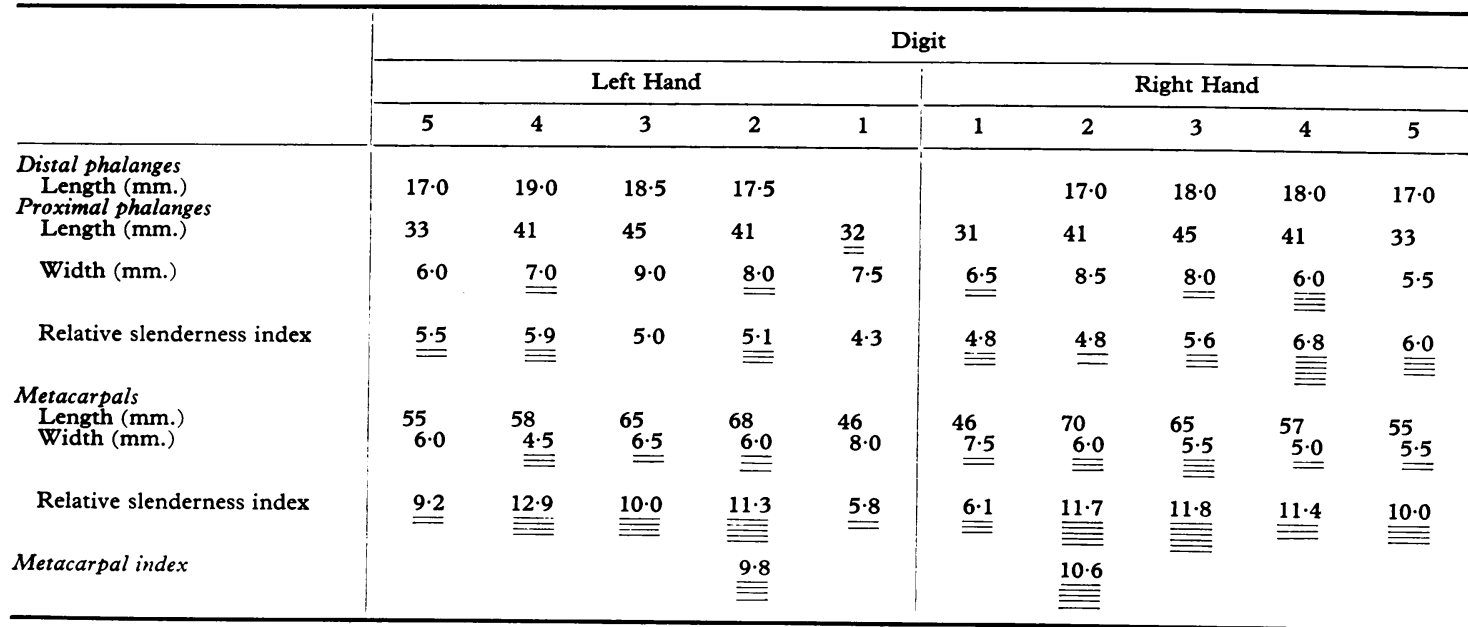

Outside 2 SD for elongation or slenderness, or high indices of relative slenderness.

Outside 3 SD for slenderness or high indices of relative slenderness.

Outside 4 SD for slenderness, high indices of relative slenderness, or high metacarpal index.

Outside 5 SD for high indices of relative slenderness or high metacarpal index.

Outside 6 SD for high indices of relative slenderness. 
TABLE XII

HAND CHART OF TALL NORMAL SUBJECT

\begin{tabular}{|c|c|c|c|c|c|c|c|c|c|c|}
\hline & \multicolumn{10}{|c|}{ Digit } \\
\hline & \multicolumn{5}{|c|}{ Left Hand } & \multicolumn{5}{|c|}{ Right Hand } \\
\hline & 5 & 4 & 3 & 2 & 1 & 1 & 2 & 3 & 4 & 5 \\
\hline $\begin{array}{l}\text { Distal phalanges } \\
\text { Length (mm.) }\end{array}$ & 18.5 & $20 \cdot 5$ & $20 \cdot 0$ & $19 \cdot 0$ & & & 19.0 & $20 \cdot 0$ & 20.5 & $18 \cdot 0$ \\
\hline $\begin{array}{l}\text { Proximal phalanges } \\
\text { Length (mm.) }\end{array}$ & 34 & 43 & 46 & 41 & 32 & 32 & 42 & 46 & 44 & 34 \\
\hline $\begin{array}{l}\text { Width (mm.) } \\
\text { Relative slenderness index } \\
\text { Metacarpals }\end{array}$ & $\begin{array}{l}7 \cdot 5 \\
4 \cdot 5\end{array}$ & $\begin{array}{l}9 \cdot 0 \\
4 \cdot 8\end{array}$ & $\begin{array}{r}10 \cdot 0 \\
4.6\end{array}$ & $\begin{array}{r}10 \cdot 0 \\
4 \cdot 1\end{array}$ & $\begin{array}{l}7 \cdot 5 \\
4 \cdot 3\end{array}$ & $\begin{array}{l}7 \cdot 5 \\
4 \cdot 3\end{array}$ & $\begin{array}{r}10 \cdot 5 \\
4 \cdot 0\end{array}$ & $\begin{array}{r}10 \cdot 0 \\
4 \cdot 6\end{array}$ & $\begin{array}{l}9 \cdot 5 \\
4 \cdot 6\end{array}$ & $\begin{array}{l}7 \cdot 0 \\
4 \cdot 3\end{array}$ \\
\hline Length (mm.) & $\underline{\underline{57}}$ & 61 & 68 & $\underline{71}$ & 47 & 47 & 71 & 69 & 61 & $\underline{\underline{57}}$ \\
\hline $\begin{array}{l}\text { Width (mm.) } \\
\text { Relative slenderness index } \\
\text { Metacarpal index }\end{array}$ & $\begin{array}{l}7 \cdot 5 \\
7 \cdot 6\end{array}$ & $\begin{array}{l}6 \cdot 5 \\
9 \cdot 4\end{array}$ & $\begin{array}{l}8 \cdot 5 \\
8 \cdot 0\end{array}$ & $\begin{array}{l}9 \cdot 0 \\
7 \cdot 9 \\
8 \cdot 2\end{array}$ & $\begin{array}{r}10 \cdot 0 \\
4 \cdot 7\end{array}$ & $\begin{array}{l}9 \cdot 5 \\
4 \cdot 9\end{array}$ & $\begin{array}{l}9 \cdot 0 \\
7 \cdot 9 \\
7 \cdot 9\end{array}$ & $\begin{array}{l}9 \cdot 0 \\
7 \cdot 7\end{array}$ & $\begin{array}{l}6 \cdot 5 \\
9 \cdot 4\end{array}$ & $\begin{array}{l}8 \cdot 0 \\
7 \cdot 1\end{array}$ \\
\hline
\end{tabular}

$=$ Outside 2 SD for elongation.

Familial Streblodactyly. This curious condition was discovered in a family, in which the hands of the female members had a peculiar mixture of flexion contractures and increased mobility of the joints, imitating many of the deformities caused by rheumatoid arthritis (Parish, Horn, and Thompson, 1963). The anomaly was clearly inherited, but it was the unusual skeletal hand chart of the mother of the proposita (Table XIII) which stimulated the investigations, leading to the discovery of the abnormal urinary amino acid associated with the condition.

The second metacarpal in the right hand is abnormally broad, with readings of $4 \mathrm{SD}$ for breadth and outside 3 SD for a low index of relative slender- ness. The changes in the 2nd metacarpal of the left hand are less marked, with readings outside 2 SD for breadth and a low index of relative slenderness. The proximal phalanx of the same finger in the left hand is outside 2 SD for slenderness, due to rotation of the shaft of the bone associated with the flexion deformity.

Photographs of the hands of this patient are illustrated in Fig. 3 and 4. The flexion deformities of the proximal interphalangeal joints of the fingers are much greater in the left hand than in the right. If these deformities influenced the bone measurements one would expect considerable differences between the skeletal hand chart recordings of the individual bones of each hand. However, the recordings of

TABLE XIII

FAMILIAL STREBLODACTYLY: HAND CHART OF FEMALE PATIENT WITH BROAD 1st AND 2nd METACARPALS

\begin{tabular}{|c|c|c|c|c|c|c|c|c|c|c|}
\hline & \multicolumn{10}{|c|}{ Digit } \\
\hline & \multicolumn{5}{|c|}{ Left Hand } & \multicolumn{5}{|c|}{ Right Hand } \\
\hline & 5 & 4 & 3 & 2 & 1 & 1 & 2 & 3 & 4 & 5 \\
\hline $\begin{array}{l}\text { Distal phalanges } \\
\text { Length (mm.) } \\
\text { Proximal phalanges }\end{array}$ & - & - & 一 & 一 & & & $14 \cdot 5$ & $16 \cdot 5$ & $16 \cdot 0$ & $13 \cdot 0$ \\
\hline $\begin{array}{l}\text { Length (mm.) } \\
\text { Width (mm.) }\end{array}$ & $\begin{array}{l}31 \\
7 \cdot 0\end{array}$ & $\begin{array}{l}38 \\
7 \cdot 5\end{array}$ & $\stackrel{41}{9 \cdot 0}$ & $\stackrel{36}{8 \cdot 0}$ & $\frac{28}{8 \cdot 5}$ & $\stackrel{28}{8 \cdot 0}$ & $\begin{array}{l}37 \\
9 \cdot 0\end{array}$ & $\stackrel{41}{9 \cdot 0}$ & $\stackrel{38}{8 \cdot 0}$ & $\begin{array}{l}31 \\
7 \cdot 5\end{array}$ \\
\hline $\begin{array}{l}\text { Relative slenderness index } \\
\text { Metacarpals }\end{array}$ & $4 \cdot 4$ & $5 \cdot 1$ & $4 \cdot 6$ & $4 \cdot 5$ & $3 \cdot 3$ & $3 \cdot 5$ & $4 \cdot 1$ & $4 \cdot 6$ & $4 \cdot 8$ & $4 \cdot 1$ \\
\hline $\begin{array}{l}\text { Length (mm.) } \\
\text { Width (mm.) }\end{array}$ & $\begin{array}{l}50 \\
8 \cdot 0\end{array}$ & $\stackrel{53}{6 \cdot 5}$ & $\stackrel{59}{8 \cdot 5}$ & $\begin{array}{l}62 \\
9 \cdot 5 \\
: \therefore: !\end{array}$ & $\begin{array}{l}42 \\
10.5 \\
::::\end{array}$ & $\begin{array}{l}42 \\
10 \cdot 5\end{array}$ & $\begin{array}{l}64 \\
10 \cdot 5 \\
\vdots \vdots \vdots \vdots\end{array}$ & 81 & $\begin{array}{l}56 \\
6.5\end{array}$ & $\begin{array}{l}52 \\
8 \cdot 0\end{array}$ \\
\hline Relative slenderness index & $6 \cdot 3$ & $8 \cdot 2$ & $6 \cdot 9$ & $\begin{array}{l}6 \cdot 5 \\
:::\end{array}$ & $4 \cdot 0$ & $4 \cdot 0$ & $\begin{array}{l}6 \cdot 1 \\
\vdots: \vdots \vdots\end{array}$ & $7 \cdot 2$ & $8 \cdot 6$ & 6.5 \\
\hline Metacarpal index & & & & $6 \cdot 8$ & & & $6 \cdot 8$ & & & \\
\hline
\end{tabular}

$=$ Outside 2 SD for slenderness due to rotation of shaft.

:::: Outside 2 SD for breadth or low index of relative slenderness.

Outside 3 SD for low index of relative slenderness.

Outside 4 SD for breadth. 


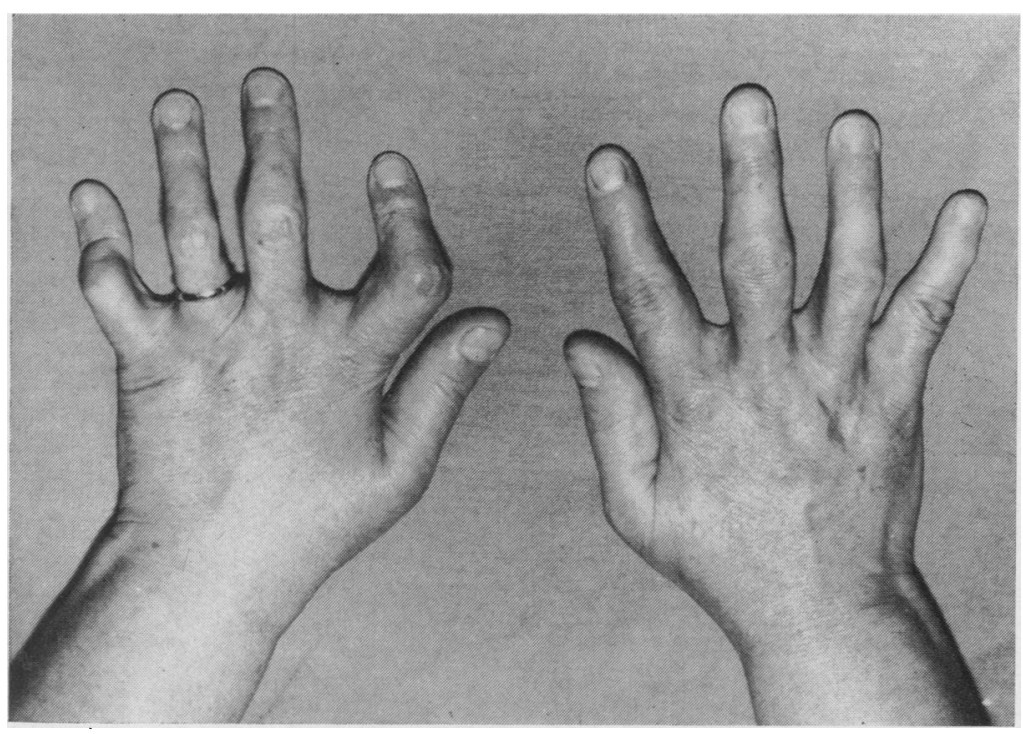

FIG. 3. Familial streblodactyly.

the two hands in Table XIII are remarkably similar, suggesting that the abnormal breadth of the 2nd metacarpal was not due to distortion of the $x$-ray film image (Fig. 5) resulting from the flexion deformity. Additional evidence to support this hypothesis was obtained from measurements of the $x$-ray films of two normal subjects, whose hands were placed so that the centres of their 2 nd proximal interphalangeal joints were $3.1 \mathrm{~cm}(1.25 \mathrm{in}$.) and the 5 th joints were $2.5 \mathrm{~cm}$. ( 1.0 in.) above the recording film with an Anode Focal Distance of $76 \mathrm{~cm}$. The films were taken with the hands in a similar position to that of the patient's left hand.

Differences in measurements recorded in this

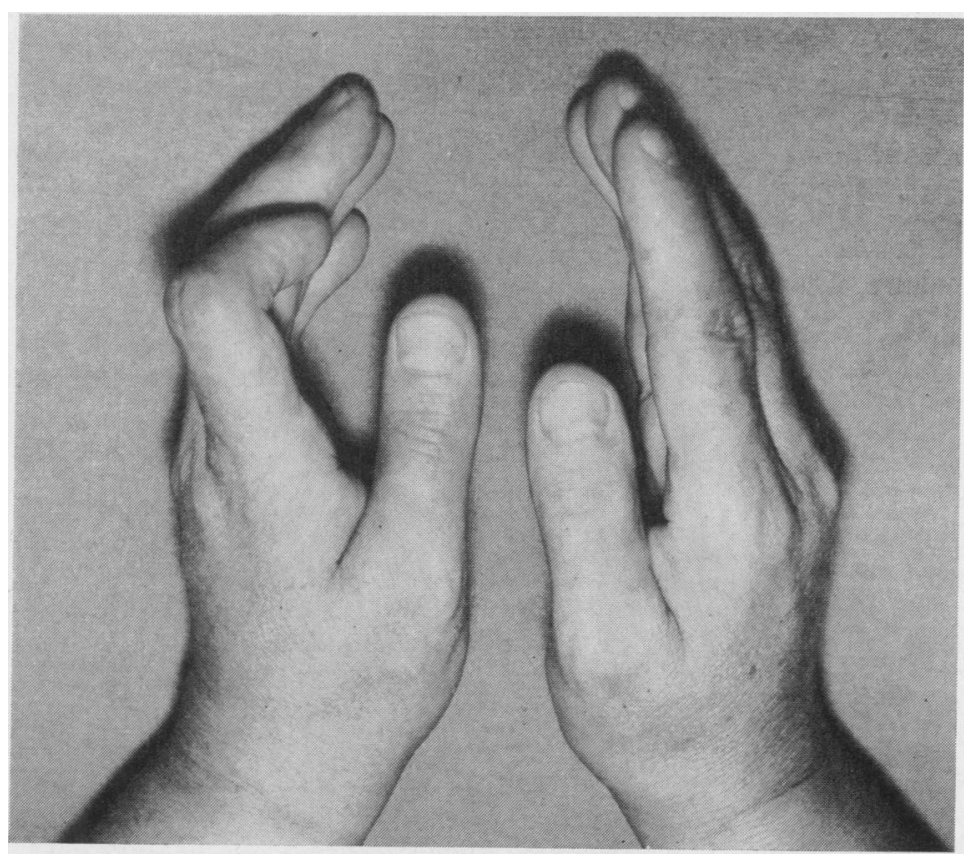

FIG. 4. Familial streblodactyly. 


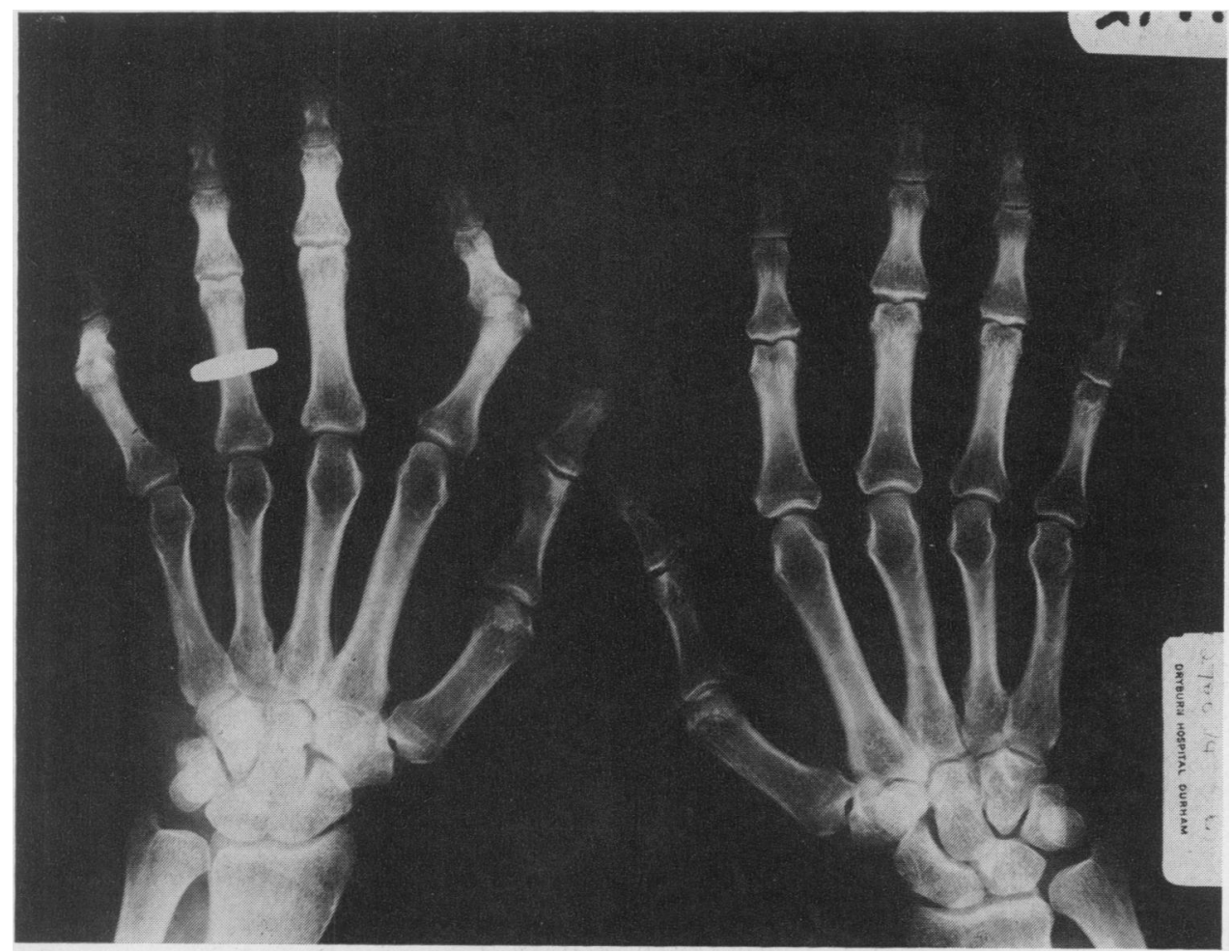

FIG. 5. Familial streblodactyly.

position, as compared with those taken from films taken in the standard position, are given in Table XIV.

The slight increase in apparent width of the 2nd metacarpal which occurs in the abnormal position is offset by a slight increase in the apparent length of the bones, so that the relative slenderness index is inconstantly affected. When films of the normal subjects were taken in a similar position to that of the patient's right hand with the centre of the proximal interphalangeal joints $0.9 \mathrm{~cm}$. $(0.75 \mathrm{in}$.) above the plate, the length of both the 2nd and 3rd metacarpals of the first subject increased by $2 \mathrm{~mm}$., but the width remained unchanged, so that the relative slenderness index increased by $0 \cdot 2$. The second subject, who had metacarpals $8 \mathrm{~mm}$. longer than the first, did not show any changes in the readings of the 2nd or 3rd metacarpals compared with the standard position.

TABLE XIV

\begin{tabular}{l|l|l}
\hline \multicolumn{1}{c|}{ 2nd Metacarpal } & 1st Subject & 2nd Subject \\
\hline Length & $\begin{array}{l}+2 \mathrm{~mm} . \\
+0.5 \mathrm{~mm} .\end{array}$ & $\begin{array}{l}+1 \mathrm{~mm} . \\
+0.5 \mathrm{~mm} . \\
-0.4\end{array}$ \\
$\begin{array}{ll}\text { Width } \\
\text { Relative slenderness index }\end{array}$ & $\begin{array}{l}0.2 \\
\end{array}$
\end{tabular}

\section{Discussion}

In recording abnormal bone shape from measurements of radiographs of the hand, it was considered that variations in the position of the hands on the film might significantly affect the readings. In order to allow for this possible error the reading of $3 \times$ Standard Deviation of the normal range was adopted as the boundary between normal and abnormal bone measurements. Measurements outside the 3 SD reading would be expected to occur less frequently than once in a population of 760 persons. The relative slenderness index in the presence of normal bone length tends to emphasize the abnormality so that readings as high as $6 \mathrm{SD}$ of the index have been recorded. This index has proved to be a much more sensitive measure of bone shape than originally anticipated. The skeletal hand chart of the patient with familial streblodactyly has shown that even when flexion deformities considerably alter the corresponding position of each hand on the radiographic film, differences between the bone measurements of the two hands are remarkably small, and the effect on the relative slenderness index is insignificant. Thus in hands unaffected by deformities, no special care need be taken in position- 
ing the hand in taking radiographs for bone measurements. In addition, readings between the 2 and 3 SD limits may indicate significant abnormality, so that it may be necessary to record measurements outside limits such as the $2.6 \mathrm{SD}$ level or one in 200 persons in future skeletal hand charts.

The object of preparing skeletal hand charts in this study was to determine whether measurements of the bones of the hands would act as a marker of the operation of genetic disorders of bone shape and of other inherited connective tissue defects. In the Marfan trait the irregularity of the expression of the abnormality in the bones of the hands is quite distinct. In fact, some of the bones in the affected hands are entirely normal in size and shape. Connective tissue in other parts of the body may also be affected in this syndrome, particularly in the cardiovascular system, where the basic defect may possibly lie in the elastic fibres or in collagen in the walls of blood vessels and in the valves of the heart (McKusick, 1966). The defective elastic fibres may rupture in response to the continued haemodynamic stress imposed by the circulation, resulting in dilatation of the corresponding blood vessels. In this system, too, the published reports suggest that the defect may be expressed irregularly. McKusick describes a patient with a well-circumscribed aneurysm of the descending aorta, diffuse dilatation of the abdominal aorta, and aortic valvular regurgitation; yet, the ascending aorta, which is most commonly affected, probably because it bears the brunt of the haemodynamic thrust, was normal. Austin and Schaefer (1957) have recorded a necropsy of a case in which the ascending aorta was only slightly dilated; the remainder of the aorta was unaffected, but the walls of the innominate and both common carotid arteries were disrupted by dissecting aneurysms. Roark (1959) presents another necropsy report of a case with the Marfan trait, in which gross changes were found in a widespread distribution, affecting aortic and mitral valves, pulmonary artery, ascending and abdominal segments of the aorta, and splenic and iliac arteries, whereas other blood vessels were normal or only minimally affected. Skeletal hand charts should be able to indicate the presence of this inherited weakness of the walls of blood vessels and so differentiate any resultant aneurysm from that due to acquired disease. Similarly, in family studies the finding of abnormal hand charts in certain members should mark the presence of potential defects in the walls of blood vessels in these persons. Exactly how closely the defects of the two systems are linked has yet to be determined.
Lynas (1958) found that the pattern of inheritance of the Marfan trait was suggestive of expression in the heterozygote by a single irregular dominant gene, with variable manifestations which might be influenced by the presence of a modifying gene or genes. She also found a mean excess of paternal over maternal age of the parents of her sporadic cases of 8 years; this has led to the view that these cases are mutations caused, partly at least, by the high paternal age (Campbell, 1965). There is considerable doubt that this is the case, as her series was small and the difference in paternal ages was largely accounted for by one family, where there was a difference of 20 years between the parents. I have recently explored the family of a so-called 'sporadic' case using skeletal hand charts and other indices of skeletal abnormality and found evidence indicating a recessive pattern of inheritance in this family.

Both the Marfan trait and familial streblodactyly are associated with biochemical abnormalities in the urine. Raised urinary hydroxyproline excretion has been recorded in patients exhibiting the Marfan syndrome (Jones, Bergman, Kittner, and Pigman, 1964). Achard's syndrome may be the expression of yet another biochemical defect. The nature of the link between these biochemical disorders and the bone changes analysed in the skeletal hand charts has yet to be discovered.

Although the classical triad of arachnodactyly, cardiac, and ocular abnormalities is rare, modified forms of the Marfan syndrome, presenting with skeletal deformities, are relatively common. Clinically, the distinction between these patients and normal patients with rather long fingers is often difficult. Even the experienced radiologist may be misled by radiographs of hands showing elongated bones and have difficulty in detecting abnormally slender bones, when adjacent bones are normal in shape. In other cases mild degrees of arachnodactyly may be suspected when looking at the radiographs, but the skeletal hand charts are found to be normal. But patients with abnormal indices are probably exhibiting incomplete forms of the syndrome, and are potential carriers of genes that may be responsible for heart disease and eye lesions in their offspring. The bone indices may help in deciding whether a case of congenital eye or heart disease with arachnodactyly has arisen de novo as a mutation or has been inherited from one of the parents. In the latter case other members of the family may be affected or even show other disorders of bone shape such as the appearance of the WeillMarchesani trait in a family with the Marfan syndrome described by Bowers (1959). Homocystinuria 
may also produce some of the skeletal features of the Marfan syndrome, including the occasional appearance of arachnodactyly (McKusick, 1966). Skeletal hand charts may prove to be of value in family surveys of brachymorphic conditions such as that undertaken by Lomas and Boyle (1959) in Morquio's disease.

\section{Summary}

Tables have been prepared recording the $2 \times$ Standard Deviation (2 SD) and the 3 SD from the mean of the normal range of those bone measurements used in surveys of inherited skeletal disorders and obtained from radiographs of male and female adult hands. The Tables indicate certain characteristics of bone shape, such as elongation and slenderness, and shortness and breadth.

Using these tables, skeletal hand charts have been prepared so that abnormal bone measurements lying outside 2 or $3 \mathrm{SD}$ readings are emphasized, and examples have been depicted of hand charts of (a) the first case of arachnodactyly described by Achard in 1902; (b) the first case of Achard's syndrome described in this country; (c) the Marfan syndrome, showing the very irregular expression of the genetic defect with normal digits adjacent to highly abnormal ones; and (d) familial streblodactyly: the finding of abnormally broad second metacarpals in a skeletal hand chart of a patient with familial deformity of the hands, resembling that produced by rheumatoid arthritis, led to the discovery of a hitherto unrecorded aminoaciduria.

The irregular expression of the Marfan trait in the bones of the hands may be an indicator of a similarly irregular weakness in the walls of arteries described in the reports of this condition.
I am indebted to Dr. G. T. Holroyd, Durham, and Dr. H. E. Duggan, University of Alberta Hospital, for their co-operation with the radiological studies; to Dr. A. N. Zinovieff, Durham, for his help and advice; and to Dr. M. Thompson, Department of Physical Medicine, Newcastle upon Tyne, with whom I collaborated in the investigation of the patients with familial streblodactyly. Photography was undertaken by the University of Newcastle upon Tyne.

\section{REFERENCES}

Achard, M. C. (1902). Arachnodactylie. Bull. Mém. Soc. Méd. Hop. Paris, 19, 834.

Austin, M. D., and Schaefer, R. F. (1957). Marfan's syndrome, with unusual blood vessel manifestations. Primary medionecrosis dissection of right innominate, right cartoid and left carotid arteries. Arch. Path., 64, 205.

Boerger, F. (1914). Ein Fall von Dolichestenomelie (Arachnodactylie). Mschr. Kinderheilk., 13, 355.

Bowers, D. (1959). Marfan's syndrome and the Weill-Marchesani syndrome in the S. family. Ann. intern. Med., 51, 1049.

Campbell, M. (1965). Causes of malformations of the heart. Brit. med. $\mathcal{F} ., 2,895$.

Jones, C. R., Bergman, M. W., Kittner, P. J., and Pigman, W. W. (1964). Urinary hydroxyproline excretion in Marfan's syndrome as compared with age matched controls. Proc. Soc. exp. Biol. $(N . Y), 116,931$.

Lomas, J. J. P., and Boyle, A. C. (1959). Osteochondrodystrophy (Morquio's disease) in three generations. Lancet, $2,430$.

Lynas, M. A. (1958). Marfan's syndrome in Northern Ireland; an account of thirteen families. Ann. hum. Genet., 22, 289.

McKusick, V. A. (1966). Heritable Disorders of Connective Tissue, 3rd ed., pp. 66, 124, and 176. Mosby, St. Louis.

Marfan, A. B. (1896). Un cas de déformation congénitale des quatre membres plus prononcée aux extrémités charactérisée par l'allongement des os avec un certain degré d'amincissement. Bull. Mém. Soc. Méd. Hôp. Paris, 13, 220

Parish, J. G. (1960). Skeletal syndromes associated with arachnodactyly. Proc. roy. Soc. Med., 53, 515.

- (1966). Radiographic measurements of the skeletal structure of the normal hand. Brit. F. Radiol., 39, 52.

, Horn, D. B., and Thompson, M. (1963). Familial streblodactyly with amino-aciduria. Brit. med. F., 2, 1247.

Roark, J. W. (1959). Marfan's sydrome. Report of one case with autopsy, special histiological study and review of the literature. Arch. intern. Med., 103, 123.

Salle, V. (1912). Ueber einen Fall von angeborener abnormen Grosse der Extremitaten mit einen an Akronemegalia erinnerden Symptomenkomplex. $\mathscr{F b}$. Kinderheilk., 75, 540.

Sinclair, R. J. G., Kitchin, A. H., and Turner, R. W. D. (1960). The Marfan syndrome. Quart. F. Med., 29, 19. 